\title{
Migraine as a risk factor associated with hypertensive disorders of pregnancy
}

\author{
Enxaqueca antes da gravidez como fator associado para distúrbios \\ hipertensivos da gestação
}

\begin{abstract}
Gabriel Braga Diégues Serva', Leonardo Santos Calvacanti Guerra', Vilneide Maria Santos Braga Diégues Serva², Waldmiro Antônio Diégues Serva ${ }^{3}$, Marcela Patrícia Macêdo Belo4, Marcelo Moraes Valença ${ }^{5}$, Maria de Fátima Costa Caminha ${ }^{6}$

'Medical Doctor, Faculdade Pernambucana de Saúde (FPS). Recife, PE, Brazil ${ }^{2} \mathrm{MsC}$ in Mother and Child Heath at the University of London and Head of the Breast Milk Bank and Center of Incentive of Breastfeeding at IMIP (BLH/CIAMA/IMIP). Recife, PE, Brazil ${ }^{3} \mathrm{PhD}$ in Neurophychiatry and Behavior Sciences of the UFPE, Mphill in Neuroradiology at the University of London, Associate Professor of the Department of Neuropsychiatry of the UFPE. Recife, PE, Brazil ${ }^{4}$ Nurse Resident in Pediatrics at the IMIP and MsC student in Pediatrics of the UFPE. Recife, PE, Brasil ${ }^{5} \mathrm{PhD}$ in Physiology (USP - Ribeirão Preto) and Associate Professor at the Department of Neuropsiquiatry of the Federal University of Pernambuco (UFPE). Recife, PE, Brazil ${ }^{6} \mathrm{PhD}$ in Nutrition at the Universidade Federal de Pernambuco (UFPE) and Researcher at the Research Department the of the Instituto de Medicina Integral Professor Fernando Figueira (IMIP). Recife, PE, Brazil
\end{abstract}

Serva GB, Guerra LS, Serva VM, Serva WA, Belo MP, Valença MM, Caminha MF. Migraine as a risk factor associated with hypertensive disorders of pregnancy. Headache Medicine. 2014;5(2):33-38

\begin{abstract}
Objectives: To identify if the presence of migraine before pregnancy predisposes to hypertensive disorders of pregnancy. Methods: Observational study undertaken from a database of a follow-up study, composed of women consecutively assisted, at the first postnatal week, at IMIP. Its objective was to evaluate the course of migraine during pregnancy and postpartum in women with migraine before pregnancy. The Fisher exact test was used considering the significance level of less than 5\%. Results: Of the 686 women, 38.8\% were migraine sufferers before pregnancy. $14.3 \%$ referred hypertensive disorders of pregnancy. The presence of migraine before pregnancy and to have been submitted to a cesarean section $(p<0.001)$ were factors associated with the presence of hypertensive disorders in pregnancy. Conclusion: Migraine before pregnancy is an associated factor to hypertensive disorders of pregnancy. The diagnosis of migraine should always be taken into consideration during antenatal care, for the prevention of complications.
\end{abstract}

Keywords: Migraine with aura; Migraine without aura; Pregnancy; Hypertension

\section{RESUMO}

Objetivos: Identificar se a enxaqueca antes da gravidez predispõe aos distúrbios hipertensivos da gestação. Método: Estudo observacional, realizado a partir de banco de dados, composto por mulheres consecutivamente assistidas na primeira semana pós-parto em hospital de referência no Nordeste do Brasil. Foi utilizado o teste exato de Fisher considerando o nível de significância menor que 5\%. Resultados: Das 686 puérperas, 38,8\% eram portadoras de enxaqueca antes da gestação. 14,3\% referiram distúrbios hipertensivos na gestação. Ter enxaqueca antes da gravidez e ser submetida à cesariana $(p<0,001)$ mostraram-se como fatores associados aos distúrbios hipertensivos na gestação. Conclusão: Enxaqueca antes da gravidez é um fator associado aos distúrbios hipertensivos da gestação. diagnóstico da enxaqueca deve ser sempre levado em consideração no pré-natal para que haja prevenção de complicações.

Palavras-chave: Enxaqueca sem aura; Enxaqueca com aura; Gravidez; Hipertensão. 


\section{INTRODUCTION}

Migraine is a primary headache considered by the World Health Organization in the nineteenth place among all diseases causing incapacity. ${ }^{(1)}$

In 1938, Graham and Wolff(2) were the first to develop a consistent theory to explain migraine attacks. They claimed that there was an initial intracranial vasoconstriction followed by vasodilatation, causing aura and pain, respectively. Currently, there is evidence that the pain in migraine is mediated by the trigeminal nerve and that this may be due to a form of neurogenic inflammation..$^{(3)}$ The vasodilatation caused by stimulation of the Gasserian ganglion is accompanied by the mast cells degranulation and increased vascular permeability with release of neuropeptides. ${ }^{(3)}$

Furchgott and Zawadzki(4) reported that vasodilatation induced by acetylcholine depended on an intact endothelium, but nitric oxide, the mediator of this endothelium-dependent vasodilatation was identified, also plays a role in hyperalgesia. ${ }^{(5)}$ On the other hand, gestational hypertension and preeclampsia are disorders that arise during pregnancy, after the twentieth week. ${ }^{(6)}$

The physiopathology of hypertensive disorders of pregnancy, especially preeclampsia, is not yet fully known, but it is known that it is multifactorial, involving multiple organs and even genetic and immunological factors. $\left.{ }^{6}, 7\right)$

During normal pregnancy, the uterine spiral arteries are transformed from high-resistance vessels into lowresistance ones, to meet the needs of the growing fetus. This transformation is the result of trophoblastic invasion of the arterial layers. In women with preeclampsia, trophoblastic invasion ceases to occur, or occurs inappropriately, resulting in high resistance vessels and placental circulation with low flow. Placental ischemia and hypoxia determine injury of the the vascular endothelium. Then, a vicious circle follows up. Placental hypoxia increases the production of free radicals which damage the endothelium. Endothelial injury, in turn, triggers platelet activation, the release of thromboxane (TXA2) and serotonin and platelet aggregation, with obstruction of placental blood flow. The placental hypoxia also increases the production of lipid peroxides which damage the synthesis of prostacyclin, a potent vasodilatator. ${ }^{(8)}$ Thus, the vascular changes that occur in hypertensive disorders of pregnancy are similar to those in migraine. ${ }^{(6,9)}$

That is why, the etiological relationship between the two conditions needs investigation because it remains relatively obscure. (10) The literature reports a high risk for pregnancy-induced hypertension or preeclampsia, among women with migraine before pregnancy. ${ }^{(9-13)}$

So, the present study investigated whether migraine before pregnancy predisposes to hypertensive disorders of pregnancy.

\section{METHODS}

This is an observational study undertaken from the database of a follow-up study with two components (prospective and retrospective), whose main objective was to evaluate the course of migraine with (MA) and without aura $(\mathrm{MO})$ during pregnancy and postpartum among women identified as migraine sufferers before pregnancy, classified according to International Classification of Headache Disorders (ICHD-2004). (1) Data collection was conducted from June to November 2009, at the Breast Milk Bank of the Instituto de Medicina Integral Professor Fernando Figueira (BMB/IMIP). For the present study, variables related to socio-demographic, obstetric and biological characteristics were selected, according to the research objectives.

The sample used in the initial research that was part of the follow-up study was composed of mothers who had given birth at the IMIP. The data collection instrument was applied in the first postnatal visit around the eighth day after birth (between the seventh and tenth) at the Outpatient Clinic of the BMB/IMIP, after signing the Consent Form. Women with neurological diseases that characterized secondary headache before pregnancy (epilepsy, aneurysm, brain tumor, vascular malformation) were excluded. There was no bias in the sample selection, given the fact that all women were consecutively admitted in the study. The sample for the current study consisted of 686 mothers, the same as the total sample of the original database. There has been no refusal to participate.

The data collection form included questions related to socio-demographic (education, per capita income, maternal age, race/color of the skin, marital status, occupation), obstetric (number of pregnancies and hypertensive disorders of pregnancy) and biological factors (MO and MA before pregnancy). All the possible categories of hypertension during pregnancy (preeclampsia/eclampsia, chronic hypertension, preeclampsia superimposed on chronic hypertension or nephropathy and gestational hypertension) were grouped under the nomination of hypertensive disorders in pregnancy. 
For the processing of the data from the follow-up study, Epi-info version 6.04.b was used with double data entry. From this database, we selected the variables of interest that allowed to identify and compare the frequency of hypertensive disorders of pregnancy in patients with or without migraine before pregnancy, thus, an "ad hoc" database was undertaken. The comparative analysis was performed using Fisher's exact test. The significance level of $<5 \%$ was used to reject the null hypothesis. Data were processed with SPSS for Windows, version 13.1 (SPSS Inc., Chicago, IL, USA). To describe the sample categorical variables were expressed in terms of absolute and relative frequencies. For continuous data, according to its distribution, the result was described by a measure of central tendency and its associated dispersion.

The present study is in accordance with Resolution 196/96 of the National Ethics Committee. It was approved in a regular meeting of the Ethics Committee of the IMIP on December 12 $12^{\text {th }}, 2011$, under the number 2747-11. The authors asked the Ethics Committee on Human Research of IMIP to liberate the Consent Form, since the article had, as source of information, a database approved by the same Committee at a Regular Meeting of April 16 th, 2009 , under the number 1389.

\section{RESULTS}

The sample consisted of 686 postpartum women who corresponded to the total sample of the original study. 266 (38.8\%) were identified as having migraine before pregnancy, where 237 (34.5\%) had MO and 29 (4.3\%) $M A$, respectively.

The mean age was 25 years, varying from 13 to 46 years old. $71.7 \%$ had nine or more years of schooling, $74.8 \%$ per capita income less than half of the minimum wage, and $55.0 \%$ reported themselves as brown [most of them were married or had a consensual union (79.7\%), primigravids (57.1\%) and did not work (59.9\%)]. The majority of them had vaginal deliveries (66.5\%).

Of the 686 women, 98 (14.3\%) reported that they had suffered hypertensive disorders of pregnancy. Of these $60(22.6 \%)$ occurred in women with MO and MA before pregnancy and 38 (9.0\%) among the other women.

Table 1 shows analyzes the factors associated with hypertensive disorders during pregnancy. The presence of migraine before pregnancy and to have been submitted to a cesarean section $(p<0.001)$ were factors associated with the presence of hypertensive disorders in pregnancy.

\section{DISCUSSION}

During childhood, girls and boys have similar prevalence of migraine, however, after puberty there is a clear predominance among women. ${ }^{(14)}$ Lipton et al., ${ }^{(15)}$ in a prospective and community based study, showed a prevalence of migraine during the women's reproductive life of $25 \%$. In the study by Maggioni et al.(16) where the interviews were conducted after delivery, asking retrospectively about the presence of $\mathrm{MA}$ and $\mathrm{MO}$ before pregnancy, the prevalence was $29 \%$. The frequency was higher in the present study where $38.8 \%$ of the women suffered from MA and MO before pregnancy. This difference can be justified because it was a hospital centered sample, with data collection performed retrospectively, although consecutively, which reduced the possibility of bias. However, a prospective study of 720 pregnant women followed from the $11^{\text {th }}-16^{\text {th }}$ week of gestation until postpartum showed a prevalence of $38.5 \%$. $25.5 \%$ of these women were $\mathrm{MO}$ sufferers, $5 \%$ had MA and $6.9 \%$ were probable migraine sufferers. ${ }^{\left({ }^{9}\right)}$ The present study did not show different results, showing frequencies of $34.5 \%$ and $4.3 \%$ for $M O$ and $M A$, respectively. Facchinetti et al. ${ }^{(9)}$ concluded that the prevalence of migraine in their study, greater than other studies in the literature, ${ }^{(15,16)}$ was not due to selection bias, since the subjects were recruited from the general population. They believed that their finding were consistent with the age range studied and also because it was a population of white women who have a higher prevalence of migraine. ${ }^{(9)}$ That was not true in the present study, where the sample was mostly composed of women who referred themselves as brown or black (74.5\%).

Hypertensive disorders of pregnancy were present in $14.3 \%$ of the pregnant women. This finding did not differ with those of the literature that shows a prevalence of 10 to $22 \%$ of hypertensive disorders of pregnancy, being the most common complication of the gestational period. ${ }^{17,18)}$ Another observational and retrospective study in a referral hospital in Recife, evaluating medical records of 12,272 pregnant women, showed that $10.26 \%$ of them met the inclusion criteria for hypertension, both gestational and chronic hypertension ${ }^{(19)}$ and again reporting similar frequency of that of the present study.

Women with migraine before pregnancy suffer a significant and progressive decrease of their seizures during the gestational period. (20,21) However, these women are at greater risk for developing gestational hypertension, preeclampsia and eclampsia..$^{(9-13)}$ Although 
Table 1. Frequency distribution of postpartum women with hypertensive disorders of pregnancy according to biological, socio-demographic and obstetric characteristics

\begin{tabular}{|c|c|c|c|c|c|}
\hline \multirow[t]{3}{*}{ Variables } & \multicolumn{4}{|c|}{ Hypertensive disorders during pregnancy } & \multirow[t]{3}{*}{$p^{\star}$} \\
\hline & \multicolumn{2}{|c|}{ Yes $(n=98)$} & \multicolumn{2}{|c|}{ No $(n=588)$} & \\
\hline & $\mathbf{n}$ & $\%$ & $\mathbf{n}$ & $\%$ & \\
\hline MO and MA before pregnancy & & & & & $<0.001$ \\
\hline Yes & 60 & 61.2 & 206 & 35.0 & \\
\hline No & 38 & 38.8 & 382 & 65.0 & \\
\hline Years of schooling & & & & & 0.309 \\
\hline$\leq 4$ & 7 & 7.1 & 31 & 5.3 & \\
\hline 5 to 8 & 27 & 27.6 & 129 & 21.9 & \\
\hline$\geq 9$ & 64 & 65.3 & 428 & 72.8 & \\
\hline Per capita income (MW) & & & & & 0.385 \\
\hline$<0.5$ & 75 & 76.5 & 438 & 74.5 & \\
\hline$\geq 0.5$ & 23 & 23.5 & 150 & 25.5 & \\
\hline Age in years & & & & & 0.142 \\
\hline$<20$ & 10 & 10.2 & 93 & 15.8 & \\
\hline 20 a 35 & 76 & 77.6 & 450 & 76.5 & \\
\hline 36 or more & 12 & 12.3 & 45 & 6.7 & \\
\hline Race/skin color & & & & & 0.451 \\
\hline White & 20 & 20.4 & 155 & 26.4 & \\
\hline Black & 21 & 21.4 & 433 & 73.6 & \\
\hline Brown & 57 & 58.2 & 320 & 54.4 & \\
\hline Marital status & & & & & 0.265 \\
\hline Single & 17 & 17.4 & 122 & 20.8 & \\
\hline Married/consensual union & 81 & 82.7 & 466 & 79.3 & \\
\hline Ocupation & & & & & 0.478 \\
\hline Work/Study & 40 & 40.8 & 235 & 57.0 & \\
\hline Do not work & 58 & 59.2 & 353 & 43.0 & \\
\hline Number of pregnancies & & & & & 0.457 \\
\hline 1 & 57 & 58.2 & 335 & 57.0 & \\
\hline$>1$ & 41 & 41.8 & 253 & 43.0 & \\
\hline Type of delivery & & & & & $<0.001$ \\
\hline Normal & 49 & 50.0 & 407 & 69.2 & \\
\hline Cesarean & 49 & 50.0 & 181 & 30.8 & \\
\hline
\end{tabular}

$\mathrm{MO}=$ Migraine without aura; $\mathrm{MA}=$ Migraine with aura; and $\mathrm{MW}=$ Minimum wage $(\mathrm{R} \$ 465.00)$

${ }^{\star}$ Fisher's exact test

the primary mechanisms of migraine and preeclampsia are not completely understood, both diseases are characterized by having an altered vasoreactivity and platelet abnormal behavior, ${ }^{(9-11)}$ and can therefore share a common etiology. ${ }^{(12)}$ It is believed that migraine as well as gestational hypertension, preeclampsia and eclampsia have some characteristics that may increase the risk of ischemic disorders ${ }^{(9)}$ due to vascular alterations that occur in such conditions, as platelet hyperaggregation, ${ }^{(22,23)}$ reduced magnesium availability ${ }^{24,25)}$ and decreased production of prostacyclines. ${ }^{(26,27)}$ Although the latest physiological findings suggest that migraine is more a disorder of the nervous system, rather than of the vascular system, ${ }^{(13)}$ Kruit et al. ${ }^{(28)}$ showed that patients with migraine have an increased risk of developing subclinical brain infarcts.

The risk of developing hypertensive disorders of pregnancy was higher in patients with migraine before pregnancy $(9.1 \%)$ compared with those without the disease (3.1\%), adjusted for age, family history of hypertension and smoking with the OR of 2.85 (95\% IC 1.40-5.81). ${ }^{(9)}$ In that study, hypertension was defined as the onset of gestational hypertension and preeclampsia. They excluded women with chronic hypertension before pregnancy and those who had suffered from hypertensive disorders of pregnancy in previous gestational periods. ${ }^{(9)}$ Both women with $\mathrm{MO}$ and MA before pregnancy showed gestational hypertension and preeclampsia during 
pregnancy in a similar frequency, $10.3 \%$ and $11.1 \%$, respectively. ${ }^{(9)}$ Adeney et al. ${ }^{(13)}$ showed that a history of migraines before pregnancy increased by 1.8 times the risk of preeclampsia $(95 \% \mathrm{Cl} 1.1-2.7)$. That study also highlighted the importance of age, women who were diagnosed as being migraine sufferers with 30 years or more had a higher risk of developing preeclampsia during pregnancy (OR 2.8, 95\% $\mathrm{Cl} 0.8-9,0) .{ }^{(13)}$ The association of migraine and preeclampsia in overweight women compared to controls without migraine and without overweight was even greater, with a 12 fold greater risk of preeclampsia (95\% Cl 5.9-25.7).. ${ }^{13)}$ The present study showed a statistically significant difference $p<0.001$ in relation to the association among women with $\mathrm{MO}$ and MA before pregnancy and a higher frequency of hypertensive disorders of pregnancy. All possible causes of hypertension during pregnancy were grouped under the scope of hypertensive disorders of pregnancy. Age, however, was not a statistically significant variable, probably because the age at onset of the migraine attacks was not investigated.

In the present study there was a significant higher chance of hypertensive disorders among the women with migraine versus the ones without migraine [60/266 $(22.6 \%)$ vs. $38 / 420$ (9.1\%), OR 2.928 95\%Cl 1.885 4.548] (Figure 1).

OR $2.9(95 \% \mathrm{Cl} 1.9-4.6)$

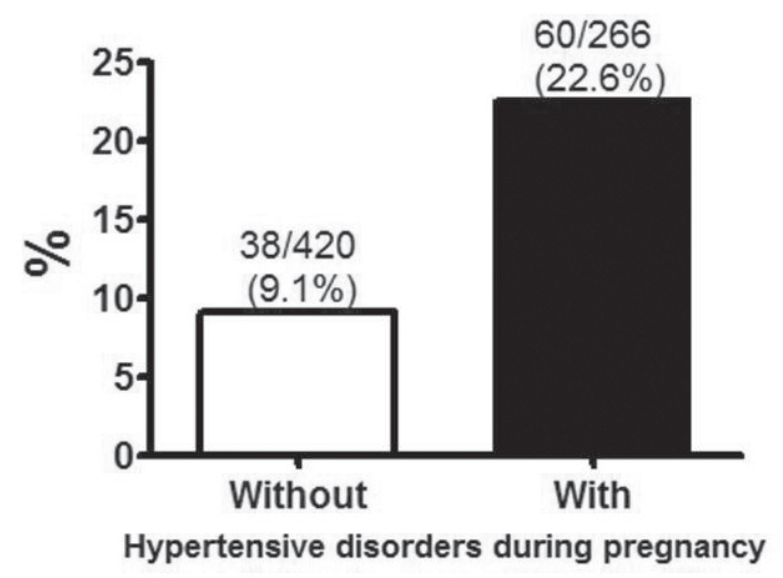

There was also an association between hypertensive disorders of pregnancy and the occurrence of cesarean section in the present study, $p<0.001$. This can be explained by the higher prevalence of cesarean sections among patients with severe hypertensive disorders, although the indication of the type of delivery should be obstetric and not solely due to the hypertensive disorders of pregnancy. ${ }^{(9)}$

Although it was not possible in the present study to classify the type of hypertension disorder of pregnancy, once the study was realized from the database collected from postpartum women, the association between migraine before pregnancy and hypertensive disorders of pregnancy may indicate that certain women are predisposed to placental ischemia and brain, and are thus at high risk for stroke and severe brain damage. ${ }^{(13)}$ There is no absolute agreement among the authors to explain the pathophysiology of migraine and hypertensive disorders of pregnancy, especially preeclampsia, however, the hemodynamics of migraine is similar to that of pre-eclampsia, with reduced perfusion, possibly mediated by endothelial dysfunction oxidative stress. ${ }^{(13)}$

In conclusion, women with migraine before pregnancy are more likely to have hypertensive disorders during the pregnancy.

\section{REFERENCES}

1. International Headache Society. The international classification of headache disorders. 2nd ed. Cephalalgia 2004;24:1 - 151 .

2. Graham JR, Wolff HG. Mechanism of migraine headache and action of ergotamine tartrate. Arch Neurol Psychiatr. 1938; 39:737-63.

3. Fortini I. Etiopatogenia e fisiopatologia. In: Speciali JG, Silva WF editores. Cefaléias. São Paulo: Lemos editorial 2002:74-86.

4. Furchgott RF, Zawadzki JV. The obligatory role of endothelial cells in the relaxation of arterial smooth muscle by acetylcholine. Nature. 1980;288(5789):373-6.

5. Flora Filho R, Zilberstein B. Óxido nítrico: o simples mensageiro percorrendo a complexidade. Metabolismo, síntese e funções. Rev Assoc Med Bras. 2000;46: 265-71.

6. Pascoal IF. Hipertensão e gravidez. Rev Bras Hipertens 2002; 9:256-61.

7. Dekker GA, Sibai BM. Etiology and pathogenesis of preeclampsia: current concepts. Am J Obstet Gynecol. 1998; 179(5): 1359-75..

8. Sharma SK. Pre-eclampsia and eclampsia. Semin Anesth Perioper Med Pain. 2000;19:171-80.

9. Facchinetti F, Allais G, Nappi RE, D'Amico R, Marozio L, Bertozzi $L$, et al. Migraine is a risk factor for hypertensive disorders in pregnancy: a prospective cohort study. Cephalalgia 2008; 29(3):286-92.

10. Adeney KL, Williams MA. Migraine headaches and preeclampsia: an epidemiologic review. Headache. 2006;46(5):794-803.

11. Facchinetti F, Allais G, D'Amico R, Benedetto C, Volpe A. The relationship between headache and preeclampsia: a case-control study. Eur J Obstet Gynecol Reprod Biol. 2004;121 (2): 143-8. 
12. Allais G, Castagnoli Gabellari I, Airola G, Schiapparelli P, Terzi $M G$, et al. Is migraine a risk factor in pregnancy? Neurol Sci. 2007;28 Suppl 2:S184-7.

13. Adeney KL, Williams MA, Miller RS, Frederick IO, Sorensen TK, Luthy DA. Risk of preeclampsia in relation to maternal history of migraine headaches. J Matern Fetal Neonatal Med 2005; 18(3): 167-72.

14. Nappi RE, Berga SL. Migraine and reproductive life. In: Aminoff MJ, Swabb DF (Ed). Handbook of Clinical Neurology: Headache. Amsterdam: Elsever BV 2011 ;24:303-322.

15. Lipton RB1, Bigal ME, Diamond M, Freitag F, Reed ML, Stewart WF; AMPP Advisory Group. Migraine prevalence, disease burden, and the need for preventive therapy. Neurology 2007;68(5):343-9.

16. Maggioni F, Alessi C, Maggino T, Zanchin G. Headache during pregnancy. Cephalalgia. 1997;17(7):765-9.

17. Sibai BM. Diagnosis and management of gestational hypertension and preeclampsia. Obstet Gynecol 2003;102(1):181-92.

18. Livingston JC, Sibai BM. Chronic hypertension in pregnancy. Obstet Gynecol Clin North Am. 2001 ; 28: 447-63.

19. Oliveira CA, Lins CP, Sá RAM, et al. Síndromes hipertensivas da gestação e repercussões perinatais. Rev Bras Saude Mater Infant. 2006;6:93-98

20. Serva WA, Serva VM, de Fátima Costa Caminha M, Figueiroa JN, Albuquerque EC, Serva GB, et al. Course of migraine during pregnancy among migraine sufferers before pregnancy. Arq Neuropsquiatr. $2011 ; 69(4): 613-9$.

21. Sances G, Granella F, Nappi RE, Fignon A, Ghiotto N, Polatti F, et al. Course of migraine during pregnancy and postpartum: a prospective study. Cephalalgia. 2003;23(3):197-205.

22. Chambers JC, Fusi L, Malik IS, Haskard DO, De Swiet M, Kooner JS. Association of maternal endothelial dysfunction with preeclampsia. JAMA $2001 ; 285(12): 1607-12$.
23. Zeller JA, Lindner V, Frahm K, Baron R, Deuschl G. Platelet activation and platelet-leucocyte interaction in patients with migraine. Subtype differences and influence of triptans. Cephalalgia 2005;25(7):536-41

24. Lopez-Jaramillo PA, Garcia RG, Lopez MB. Preventing pregnancy-induced hypertension: are there regional differences for this global problem? J Hypertens. 2005;23(6): 1121 -9.

25. Facchinetti F, Sances G, Borella P, Genazzani AR, Nappi G. Magnesium prophylaxis of menstrual migraine: effects on intracellular magnesium. Headache. 1991 ;31 (5):298-301.

26. Walsh SW. Preeclampsia: an imbalance in placental prostacyclin and thromboxane production. Am J Obstet Gynecol. 1985; 152(3):335-40

27. Mezei Z, Kis B, Gecse A, Tajti J, Boda B, Telegdy G, Vecsei L. Platelet arachidonate cascade of migraineurs in the interictal phase. Platelets. 2000; 11 (4):222-5

28. Kruit MC, van Buchem MA, Hofman PA et al. Migraine as a risk factor for subclinical brain lesions. JAMA 2004;291 (4):427-34.

Correspondence

Waldmiro Antônio Diégues Serva Rua Astronauta Neil Armstrong, 120/1302. Casa Amarela, CEP: 52060-170 - Recife, PE, Brasil Telephone: 55 (81) 3268-4638 / Fax: 55 (81) 2126-8523 e-mail:wserva@hotmail.com e-mail:amanda-aas@hotmail.com

Received: June 3,2014

Accepted: June 20, 2014 